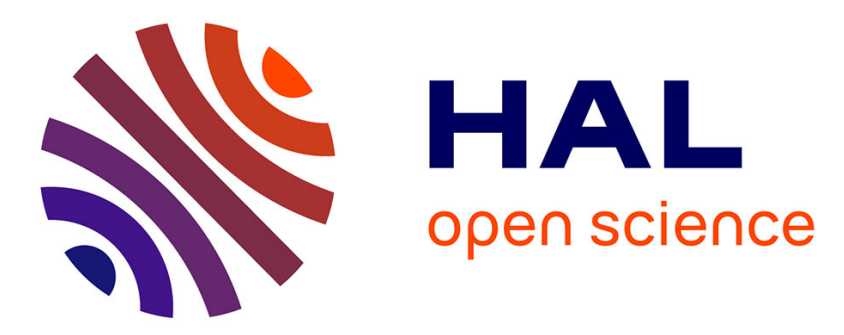

\title{
Two-Photon Sensitive Coumarinyl Photoremovable Protecting Groups with Rigid Electron-Rich Cycles Obtained by Domino Reactions Initiated by a 5- exo -Dig Cyclocarbopalladation
}

Juliane Chaud, Clément Morville, Frédéric Bolze, Delphine Garnier, Stefan

Chassaing, Gaëlle Blond, Alexandre Specht

\section{To cite this version:}

Juliane Chaud, Clément Morville, Frédéric Bolze, Delphine Garnier, Stefan Chassaing, et al.. TwoPhoton Sensitive Coumarinyl Photoremovable Protecting Groups with Rigid Electron-Rich Cycles Obtained by Domino Reactions Initiated by a 5- exo -Dig Cyclocarbopalladation. Organic Letters, 2021, 10.1021/acs.orglett.1c02778 . hal-03358286

\author{
HAL Id: hal-03358286 \\ https://hal.science/hal-03358286
}

Submitted on 29 Oct 2021

HAL is a multi-disciplinary open access archive for the deposit and dissemination of scientific research documents, whether they are published or not. The documents may come from teaching and research institutions in France or abroad, or from public or private research centers.
L'archive ouverte pluridisciplinaire HAL, est destinée au dépôt et à la diffusion de documents scientifiques de niveau recherche, publiés ou non, émanant des établissements d'enseignement et de recherche français ou étrangers, des laboratoires publics ou privés. 


\title{
Two- photon sensitive coumarinyl photoremovable protecting groups with rigid electron-rich cycles obtained by domino reactions initiated by a 5-exo-dig cyclocarbopalladation.
}

\author{
Juliane Chaud, ${ }_{\ddagger}^{\ddagger}$ Clément Morville, ${ }^{\mathrm{a}} \ddagger$ Frédéric Bolze, ${ }^{\mathrm{a}^{*}}$ Delphine Garnier, ${ }^{\mathrm{a}, \mathrm{b}}$ Stefan Chassaing, ${ }^{\mathrm{c}}$ Gaëlle \\ Blond, ${ }^{\mathrm{d}^{*}}$ and Alexandre Specht ${ }^{\mathrm{a}^{*}}$ \\ a. Laboratoire de Conception et Application de Molécules Bioactives, Université de Strasbourg, CNRS, CAMB UMR 7199, F- \\ 67000 Strasbourg, France. \\ b. Plateforme d'Analyse Chimique de Strasbourg-Illkirch, Université de Strasbourg, CNRS, PACSI GDS 3670, F-67000 Stras- \\ bourg, France. \\ c. Institut de Chimie, Laboratoire de Synthèse, Réactivité Organiques \& Catalyse, (LASYROC), Université de Strasbourg, \\ CNRS, UMR 7177, F-67000 Strasbourg, France. \\ d. Laboratoire d'Innovation Thérapeutique, Université de Strasbourg, CNRS, UMR 7200 F-67000 Strasbourg, France.
}

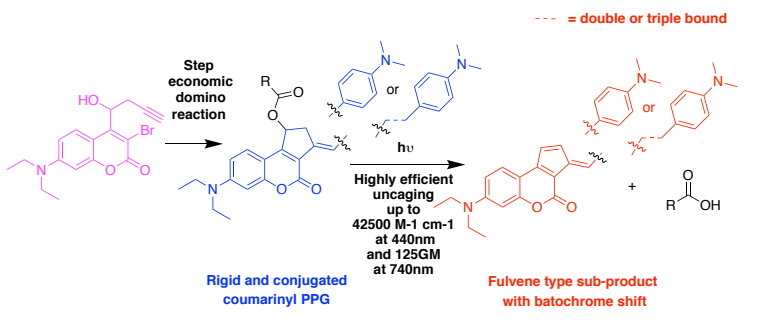

ABSTRACT: We herein report the design, synthesis and photophysical characterization of extended and rigid coumarinyl derivatives showing large two-photon sensitivities ( $\delta \mathrm{a} \Phi \mathrm{u}$ up to $125 \mathrm{GM}$ ) at 740 and $800 \mathrm{~nm}$. To efficiently synthesize these complex PPGs, stepeconomic domino reactions were used. Moreover, those new coumarinyl PPGs display unique bathochromic shifts $(\leq 100 \mathrm{~nm})$ of the uncaging sub-products as a result of the formation of a more conjugated fulvene moiety.

Photoremovable protecting groups (PPG) represent important tools in various fields of chemistry ${ }^{1,2}$ and biology. ${ }^{3}$ In particular, PPGs are used to mask the biological function of bioactive molecules, including peptides, ${ }^{4}$ proteins,${ }^{5-7}$ nucleic acids, ${ }^{8}$ neurotransmitters $^{9}$ and lipids (leading to so called caged-compounds). ${ }^{10}$ Therefore, a photolytic reaction can be used to induce a localized concentration jump of those bioactive molecules in order to rapidly initiate a wide range of dynamic biological processes. This strategy, which can be considered as seminal opto-pharmacology, was used to trigger biological responses in many fields of biology, such as neuroscience, ${ }^{9}$ cell biology, ${ }^{10}$ genetics or embryology. ${ }^{11-12}$ The development of new PPGs is largely driven by the challenge of enabling the use of visible, and red or even near-IR (NIR) light to initiate the photolytic reaction. ${ }^{2}$ In this respect, PPGs sensitive to two-photon excitation (TPE) using NIR light have been introduced ${ }^{13-17}$ to allow more sophisticated uses of those phototriggers. The advantages of NIR light include deeper $(1 \mathrm{~cm})$ tissue penetration without the toxic effects induced by higher-energy light. ${ }^{18} \mathrm{Be}-$ cause TP absorption only occurs at the focal point of a focalized laser beam, intrinsic 3D spatial resolution of the photolysis area (it can be as little as $1 \mathrm{fL}$ ) can therefore be addressed. This technique requires to develop new photoremovable groups with larger molecular TP absorption cross-sections and higher uncaging quantum yields. ${ }^{13-19}$ Molecular engineering of photoremovable protecting groups have been performed in order to increase TP absorption. ${ }^{13-}$ ${ }^{21}$ Rigidity, aromatics connected by double or triple bonds, and decoration with electron-donor and -acceptor moieties were found to contribute to the TP absorption. ${ }^{22}$ Therefore, in this article we wish to explore the effect of the incorporation of a rigid DonorDonor system on the two-photon uncaging efficiency.

Coumarinylmethyl PPGs are widely used phototriggers due to the rapid photolytic reaction (in the ns range). ${ }^{1-2}$ These latter caging groups have already been modified by $\pi$-extended electrondonating or electron-withdrawing moieties, leading to blue and green light-activatable PPGs. ${ }^{23-27}$ In most cases, those modification lead to coumarinyl PPG with only modest uncaging quantum yields. ${ }^{2,28}$ In particular, Zhu and coworkers ${ }^{25}$ introduced 7-diethylaminocoumarin (DEAC) analogues with electron-rich styryl appendages at the 3-position (1).

The styryl appendage allowed an efficient uncaging (both using one-photon excitation at $450 \mathrm{~nm}$ and TP IR excitation) and the photolytic reaction produced a lower conjugated by-product (2) through an intramolecular cyclization involving a light-generated carbocation intermediate. 
Scheme 1. Recent evolution in the structure of electron-rich styryl appendages at the 3-position of DEAC PPGs and structures designed in the present work.

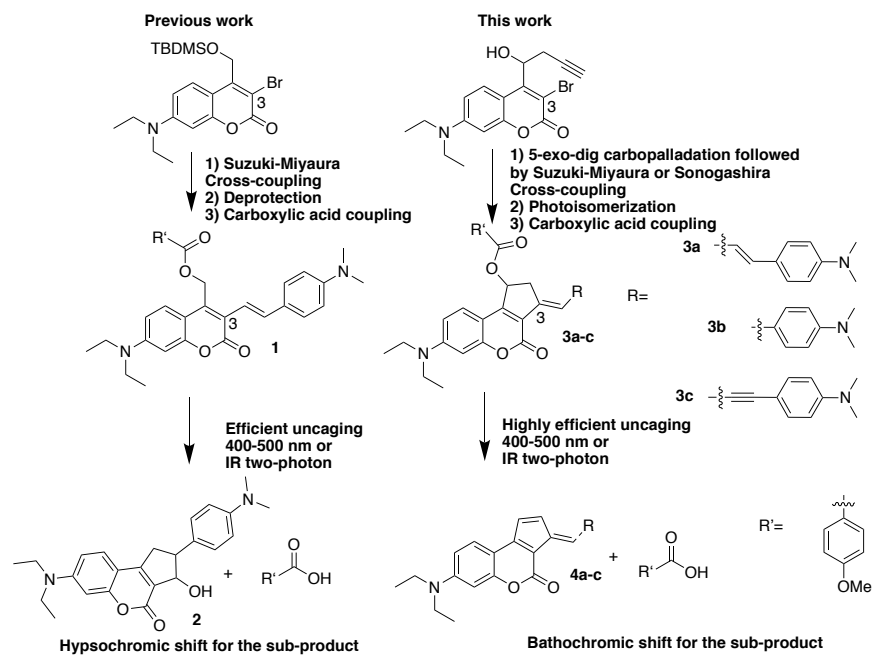

Herein, we developed $\pi$-extended and rigid coumarinyl PPGs (3a-c) at the 3-position in order to increase even further the TP absorption properties. To efficiently extend the conjugation of DEAC PPGs, we decided to exploit palladium-catalyzed crosscoupling domino reactions ${ }^{29-31}$ in order to build fused polycyclic coumarinyl PPGs. Therefore, we explored the use of a 5-exo-dig cyclocarbopalladation reaction followed by a Suzuki-Miyaura or a Sonogashira cross-coupling reaction to form various $\pi$-extended rigid coumarinyl PPGs. Using such domino reactions, 3 different rigid coumarinyl PPGs have been efficiently synthesized. More importantly, those new PPGs showed enhanced uncaging properties and allowed the formation of highly conjugated sub-products (4a-c) leading to an interesting bathochromic shift.

The propargylated DEAC analogue 6 was obtained with $86 \%$ yield by treating the aldehyde $\mathbf{5}$ with freshly prepared Scheme 2. Synthesis of coumarinyl photoremovable protecting groups 3a-c modified with rigid electron-rich cycles at the 3position.

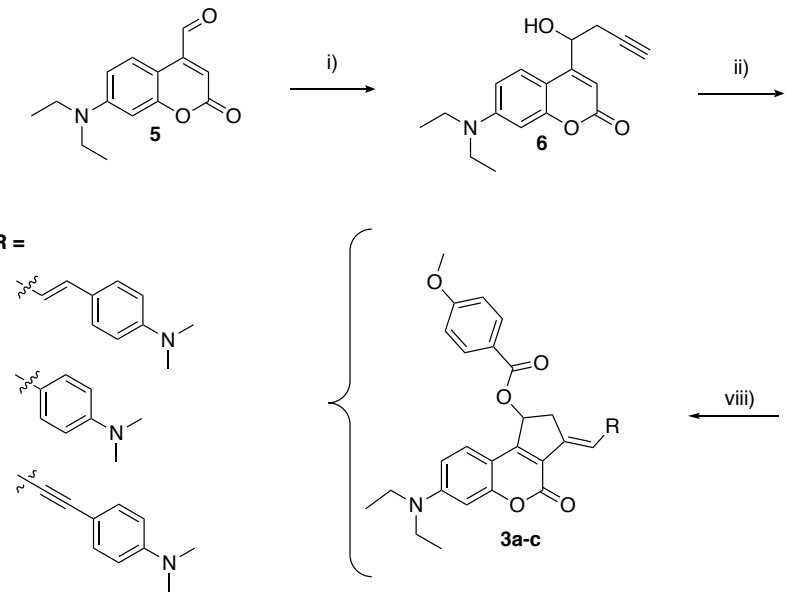

propargylzinc bromide as previously reported. ${ }^{32}$ Regioselective bromination of the 3-position of 6 was successfully performed by using $N$-bromosuccinimide in the presence of ammonium acetate as catalyst. In order to explore the efficiency of the planned domino reaction, i.e. a 5-exo-dig cyclocarbopalladation followed by a Suzuki-Myaura cross-coupling, we decided to first explore this reaction pathway on the protected alcohol $\mathbf{8}$. Therefore, compound 8 was synthesized in $56 \%$ yield. The domino reaction was performed on substrate 8 using 9a (see Supporting Information for details $), \mathrm{K}_{2} \mathrm{CO}_{3}, \mathrm{Pd}\left(\mathrm{PPh}_{3}\right)_{4}(2 \mathrm{~mol} \%)$ in a $3: 1$ mixture of $\mathrm{DME} /$ water at $105^{\circ} \mathrm{C}$ under microwave activation for 45 minutes. Because of the mechanism involves an intramolecular syn-carbopalladation step, the domino reaction should only provide the Z/E diastereoisomer 10'a, whereas an analytical HPLC analysis and NMR analysis of the crude revealed the formation of the two diastereoisomers (Z/E 10'a and E/E 10a) in an almost 8:2 ratio (see Supporting Information). Thus, we speculated that the formation of 10a resulted from the $Z$ to E photoisomerization of 10'a under ambient light exposure. Both products showed a similar UV-Visible spectrum (maximum of absorption at $460 \mathrm{~nm}$ ). It is noteworthy that, no trace of the product resulting from a direct $\mathrm{Su}-$ zuki-Miyaura cross-coupling reaction was detected in the crude mixture. The use of an internal standard enabled us to determine by NMR analysis of the crude mixture that compound 10'a was formed in $65 \%$ yield together with $12 \%$ yield of $\mathbf{1 0 a}$. After purification of the mixture, the two diastereoisomers $(\mathbf{1 0} \mathbf{a} / \mathbf{1 0 a})$ were isolated as a $62: 38$ mixture with an overall $53 \%$ yield. This latter mixture of diastereoisomers was deprotected leading to the formation of diastereoisomers $\mathbf{1 1}$ 'a/11a in $41 \%$ yield without altering the $\mathrm{Z} / \mathrm{E}$ ratio. Remarkably, when the mixture of those two diastereoisomers was irradiated (at $430 \mathrm{~nm}$ ), a complete conversion to the compound 11a (E/E) was observed.

The stereochemistry of this compound was established by ${ }^{1} \mathrm{H}-$ NOESY experiments and by the analysis of the ${ }^{1} \mathrm{H}-{ }^{1} \mathrm{H}$ coupling constants related to the diene chain.
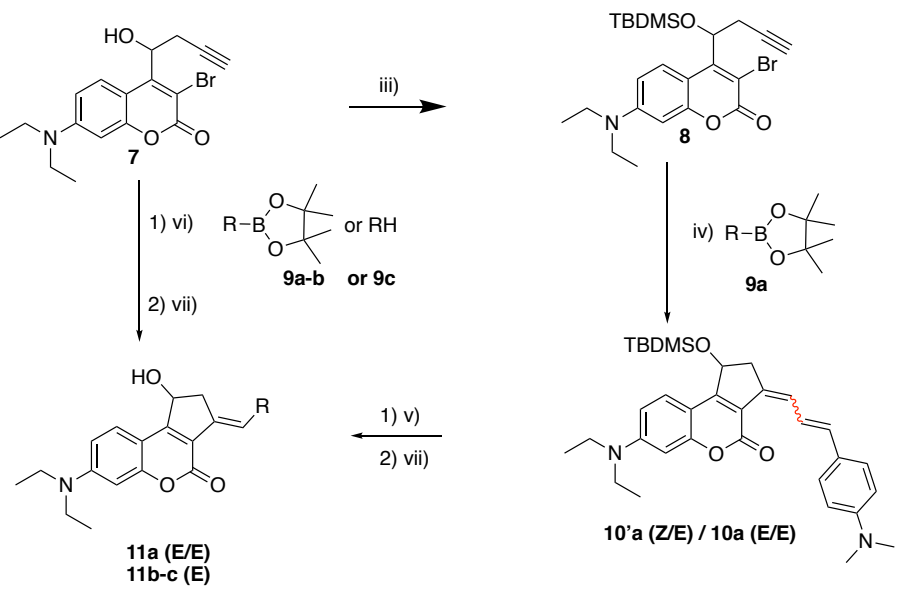

i. propargylzinc bromide, THF, $1 \mathrm{~h} 30 \mathrm{~min}, 0{ }^{\circ} \mathrm{C}$ to RT, $86 \%$; ii. NBS, ammonium acetate, anhydrous acetonitrile, $30 \mathrm{~min}, \mathrm{RT}$, $93 \%$; iii. TBDMSCl, imidazole, anhydrous DMF, 2 days, $50{ }^{\circ} \mathrm{C}$ with a heating block, 56\%; iv. Compound $9 \mathrm{a}, \mathrm{K}_{2} \mathrm{CO}_{3}, \mathrm{Pd}\left(\mathrm{PPh}_{3}\right)_{4}, \mathrm{H}_{2} \mathrm{O} / \mathrm{DME}, 45 \mathrm{~min}$, microwave $105{ }^{\circ} \mathrm{C}, 77 \%$ (calculated yield), 53\% (isolated yield); v. TBAF, THF, 30 min, RT, 41\%; vi. Compound 9a-b, $\left.\mathrm{K}_{2} \mathrm{CO}_{3}, \mathrm{Pd}_{(\mathrm{PPh}}\right)_{4}$, $\mathrm{H}_{2} \mathrm{O} / \mathrm{DME}, 45 \mathrm{~min}$, microwave $105{ }^{\circ} \mathrm{C}, 39 \%-23 \%$ (respectively for $11 \mathrm{a}$ and $11 \mathrm{~b}$ ) or compound 9c, diisopropylamine, $\mathrm{PdCl}_{2}\left(\mathrm{PPh}_{3}\right)_{2}, \mathrm{CuI}, 1 \mathrm{~h}$, microwave $120{ }^{\circ} \mathrm{C}, 47 \%$; vii. $430 \mathrm{~nm}$ irradiation, $\mathrm{CH}_{2} \mathrm{Cl}_{2}$ or chloroform, $1 \mathrm{~h}$, $\mathrm{RT}$, quant.; viii. $p$-methoxybenzoic acid, $\mathrm{DMAP}, \mathrm{DIC}, \mathrm{CH}_{2} \mathrm{Cl}_{2}$, $40.5 \mathrm{~h}$ up to 3.5 days, $0^{\circ} \mathrm{C}$ to $\mathrm{RT}, 67 \%-20 \%-38 \%$ (respectively for $3 \mathrm{a}, 3 \mathrm{~b}$ and $3 \mathrm{c}$ ). 
Beacuase TBDMS protection and deprotection are two steps with only modest reaction yields, we decided to explore the domino reaction directly on the key intermediate 7, thus in a protecting group-free manner. As planned, the expected domino reaction again took place using $9 \mathbf{a}$, but also $9 \mathbf{b}$, as boron-based coupling partner, thus leading to the formation of compounds 11a and 11b in respectively $39 \%$ and $23 \%$ yields after a purification and a subsequent photoisomerization step using a $430 \mathrm{~nm}$ LED excitation. The stereochemistry of those compounds was again established by $1 \mathrm{H}-\mathrm{NOESY}$ experiments and by the analysis of the $1 \mathrm{H}-1 \mathrm{H}$ coupling constants of relevance.

We also decided to explore the potential of a similar domino reaction, i.e., a 5-exo-dig cyclocarbopalladation followed here by a Sonogashira cross-coupling reaction, starting with 7 and the terminal alkyne $9 \mathbf{c}$ as coupling partners. Under typical catalytic conditions, the desired compound 11c was obtained in $47 \%$ yield after a photoisomerization step using a $430 \mathrm{~nm}$ LED excitation and followed by purification. The stereochemistry of this compound was established by 1D proton-coupled 13C NMR experiments (see Supporting Information). Finally, the $p$-methoxybenzoic acid ( $p$ MBA) was chosen as model cargo and compounds 3a-c were synthesized. Photophysical and photochemical characterizations and one-photon uncaging efficiencies of rigid and conjugated coumarinyl PPGs (3a-c) were characterized.

The photophysical properties of compounds 3a-c $(20 \mu \mathrm{M})$ were studied in a 9:1 (v/v) mixture of $\mathrm{MeOH} / \mathrm{H}_{2} \mathrm{O}$. These rigid PPGs show intense absorption in the visible and moderate fluorescence properties. It is noteworthy that compound $\mathbf{3 b}$ is the only compound of the three that exhibits a hypsochromic shift of the absorbance peak ( $437 \mathrm{vs} 446 \mathrm{~nm}$ ) compared to the less rigid styryl analogue $\mathbf{1}$ described by Zhu and co-workers (Scheme 1). ${ }^{25}$ More interestingly, the more conjugated compounds $\mathbf{3 a}$ and $\mathbf{3 c}$ induced a marked bathochromic shift in absorption as compared to 1. Next, the photoinduced liberation of $p$-MBA from 3a-c was monitored by UV-Visible spectroscopy and HPLC. Photolysis was carried out by irradiation of samples $(20 \mu \mathrm{M})$ at $430 \mathrm{~nm}$ (using a LUMOS 43 LED source from Atlas Photonics Inc.) in a 9:1 (v/v) mixture of $\mathrm{MeOH} / \mathrm{H}_{2} \mathrm{O}$ (Figure 1). During these photolysis experiments, compounds 3a-c showed respectively a new broad absorbance at $557 \mathrm{~nm}, 534 \mathrm{~nm}$ and $550 \mathrm{~nm}$ whilst the initial absorbance at respectively $457 \mathrm{~nm}, 437 \mathrm{~nm}$ and $452 \mathrm{~nm}$ gradually diminished. The appearance of isobestic points at respectively $497 \mathrm{~nm}, 467 \mathrm{~nm}$ and $490 \mathrm{~nm}$ were also observed, indicating homogenous reactions. An almost quantitative $(\geq 98 \%$ ) release of $p$-MBA was measured by
HPLC together with the formation of red shifted chromophores (4a-c) after complete photo-conversion of 3a-c.

The hydrolytic stability was also explored by HPLC in $\mathrm{MeCN} /$ phosphate buffer $(\mathrm{pH} 7.4,20 \mu \mathrm{M})$ mixture $(8: 2, \mathrm{v} / \mathrm{v})$ and in $\mathrm{MeOH} / \mathrm{H}_{2} 0$ mixture $(9: 1, \mathrm{v} / \mathrm{v})$ at room temperature (in the dark) indicating no significant hydrolysis after 24 hours. Altogether, this agrees with an almost quantitative photolytic reaction according to the recognized photo- $\mathrm{S}_{\mathrm{N} 1}$-dependent cleavage of coumarinbased PPGs. ${ }^{33}$ However, and in sharp contrast with 1, significant bathochromic shifts (up to $100 \mathrm{~nm}$ ) were observed for the uncaging sub-products 4a-c when tracking the UV-Vis absorption evolution of the photolysis process of our new PPGs (Figure 1). On the basis of the above results and the precedents in the literature, we can postulate a photolysis scenario for our new PPGs as shown in Scheme 3. In this scenario, we suggest as first step the formation of a free ion-pair (coumarin-based carbocation 12a-c / conjugate base of $p$-MBA) via the reversible light-induced heterolytic cleavage of the corresponding $\mathrm{C}-\mathrm{O}$ bond. Then, the so-formed carbocation intermediates 12a-c evolve towards the fulvene-based products 4a-c, via a simple irreversible deprotonation, the extension of conjugation being the driving force of the reaction. Thus, the photolytic reactions of our new coumarin-based PPGs 3a-c are suggested to take place through a photo-E1-dependent mechanistic scenario.

The quantum yields for $p$-MBA release, as determined by competition with the $p$-MBA caged analogue $1\left(\mathrm{R}^{\prime}=p\right.$-MBA, $20 \%$ uncaging quantum yield ${ }^{25}$ ) as reference molecule, were $27 \%, 57 \%$ and $26 \%$ for $\mathbf{3 a}, \mathbf{3 b}$ and $\mathbf{3 c}$ respectively, indicating excellent photochemical efficiencies at wavelengths up to $500 \mathrm{~nm}$. It is noteworthy that the clean photolytic reactions together with the important bathochromic shift of the uncaging sub-product allowed us to easily and unambiguously follow the rate of uncaging upon irradiation by UV-Visible spectroscopy. In particular, compound $\mathbf{3 b}$ showed very interesting uncaging quantum yield leading to an uncaging efficiency (defined as $\varepsilon_{\lambda \max }$. $\Phi_{u}$ ) of $24200 \mathrm{M}^{-1} . \mathrm{cm}^{-1}$. Altogether, the high photolytic efficiency and the quantitative release of $p$-MBA make those molecules remarkable PPGs for 400 to 500 $\mathrm{nm}$ uncaging experiments.

The photophysical and photochemical properties of all caged $p$ MBA analogues (3a-c) are summarized in Table 1.

In order to fully characterize the formation of the fulvene byproducts (4a), $430 \mathrm{~nm}$ irradiation of 3a was performed on preparative scale and the $\mathbf{4 a}$ by-product formation was confirmed by mass spectroscopy and by ${ }^{1} \mathrm{H}$ and ${ }^{13} \mathrm{C}$ NMR experiments.

Figure 1. Variation of UV absorbance after irradiation at $430 \mathrm{~nm}$ (using a LUMOS 43 LED source from Atlas Photonics Inc.) of $1.8 \mathrm{~mL}$ of $20 \mu \mathrm{M}$ solutions of $3 \mathrm{a}, 3 \mathrm{~b}$ and $3 \mathrm{c}$ in a 9:1 mixture of $\mathrm{MeOH} / \mathrm{H}_{2} \mathrm{O}$.
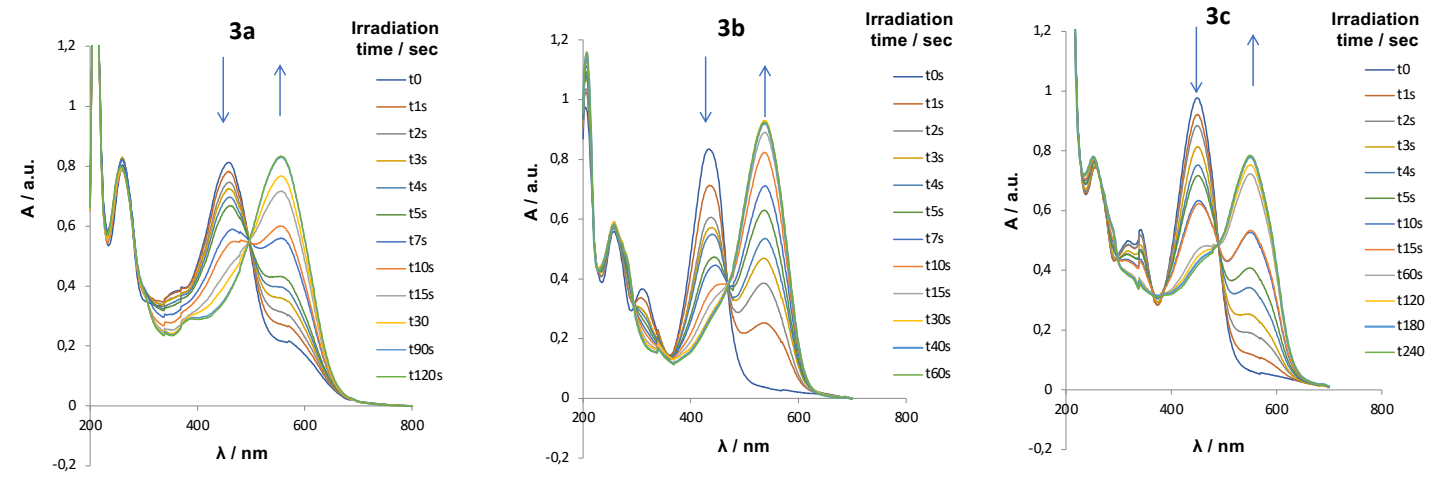
It is noteworthy that this latter by-products was poorly soluble in the NMR solvent and some other diastereoisomers of $\mathbf{4 a}$ were also observed after full irradiation. Therefore we decide to characterize compounds $\mathbf{4 b}$ and $\mathbf{4 c}$ only by mass spectroscopy. Unfortunately, all those fulvene type compounds did not show any useful fluorescent properties enabling the monitoring of the uncaging process by fluorescence. ${ }^{1}$

The TP uncaging action cross section $\left(\delta_{a} \Phi_{u}\right)$ of $\mathbf{3 a - c}$ were determined at respectively 740 and $800 \mathrm{~nm}$ by two-photon excitation followed by UV-Visible spectroscopy and compared to $p$ MBA caged analogue $1\left(\mathrm{R}^{\prime}=p\right.$-MBA $)$ as reference molecule. The TP photolysis kinetics of 3a-c and $\mathbf{1}$ are presented in Figure 2 (the quadratic dependency of the photolysis rate $v s$ the laser power was confirmed at both wavelengths, see supporting information), showing that rigid and conjugated electron-rich cycles at the 3-position of coumarinyl PPGs can induce a 4 times higher efficiency than that of $\mathbf{1}$. However, compound $\mathbf{3 b}$ only showed a weak increase presumably due to the less conjugation caused by steric hindrance between $p$-dimethylaminobenzene part and $-\mathrm{CH}_{2}$ - on five-membered ring. This study demonstrates that rigid and conjugated coumarinyl PPGs can indeed enhance both uncaging efficiency and $2 \mathrm{PA}$ properties. As a result, coumarin derivative $3 \mathbf{c}$ shows unprecedented uncaging $2 \mathrm{P}$ sensitivity at $740 \mathrm{~nm}$.

Scheme 3. Proposed mechanistic scenario for the photolytic reactions of compounds 3 a-c.

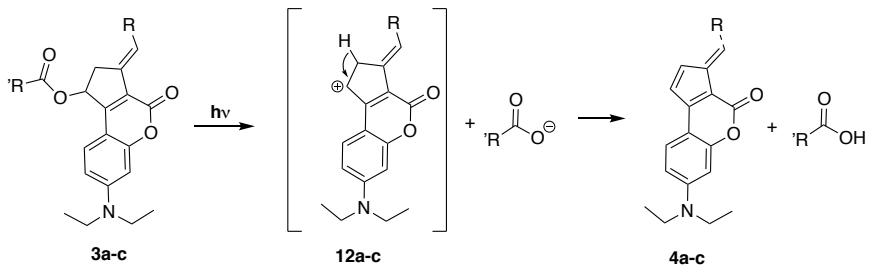

Table 1. Photophysical and photochemical properties of 1 and 3a-c in $\mathrm{MeOH} / \mathrm{H}_{2} \mathrm{O}$ mixture $(9: 1, \mathrm{v} / \mathrm{v})$ at $20^{\circ} \mathrm{C}$, "estimated from 3a-c full photolysis.

\begin{tabular}{|c|c|c|c|c|c|}
\hline Cpd. & $\begin{array}{l}\text { Abs. } \\
\lambda_{\max }(\mathrm{nm}) / \\
\varepsilon\left(\mathrm{M}^{-1} \mathrm{~cm}^{-1}\right)\end{array}$ & $\begin{array}{l}\text { Fluo. } \\
\lambda_{\max } \\
(\mathrm{nm}) / \Phi\end{array}$ & $\begin{array}{l}\text { Sub-product } \\
\text { Abs. } \\
\lambda_{\max }(\mathrm{nm}) / \varepsilon \\
\left(\mathrm{M}^{-1} \mathrm{~cm}^{-1}\right)\end{array}$ & $\Phi_{\mathrm{u}^{[\mathrm{c}]}}$ & $\begin{array}{l}\delta a \Phi_{\mathrm{u}} \\
740 / 800 \\
\mathrm{~nm} \\
(\mathrm{GM})\end{array}$ \\
\hline 1 & $446 / 41000$ & $510 / 0.02$ & $385 / 14000$ & 0.2 & $32 / 8$ \\
\hline $3 a$ & $457 / 39000$ & $609 / 0.016$ & $557 / 45300^{*}$ & 0.27 & $63 / 23$ \\
\hline $3 b$ & $437 / 42500$ & $588 / 0.042$ & $534 / 44700^{*}$ & 0.57 & $42 / \mathrm{ND}$ \\
\hline $3 c$ & $452 / 45800$ & $556 / 0.018$ & $550 / 36800^{*}$ & 0.26 & $125 / 29$ \\
\hline
\end{tabular}

Altogether, the use of step-economic domino reactions including cyclocarbopalladation allowed us to efficiently substitute coumarinyl PPGs by rigid and conjugated electron-rich cycles at the 3-position. This modification led to a significant improvement on the one-photon efficiency of the photolytic reaction (up to $57 \%$ quantum yield for one-photon photoconversion for compound $\mathbf{3 b}$ ). In addition, a very unique bathochromic shift (up to $100 \mathrm{~nm}$ ) of the uncaging sub-products was observed for those type of coumarinyl PPGs as a result of the formation of a more conjugated fulvene product 4. Most importantly, the incorporation of a rigid electron-rich and conjugated five-membered ring cycle at the 3-position of coumarinyl PPGs significantly increased the TP sensitivity, leading to an unprecedented TP uncaging action cross-section at $740 \mathrm{~nm}$ (up to $125 \mathrm{GM}$ ).
Figure 2. Two-photon excited photolysis of 3a-c at $740 \mathrm{~nm}$ (left) and $800 \mathrm{~nm}$ (right) followed by UV-Visible analysis and compared to the reference molecule 1.
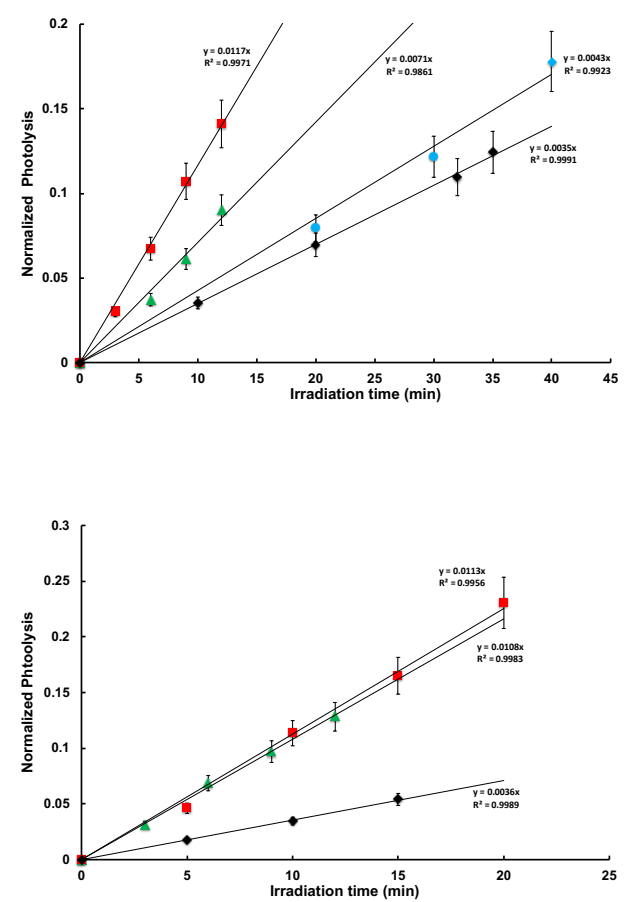

1 : black diamond; $3 \mathrm{a}$ : green triangle; $3 \mathrm{~b}:$ blue circle; $3 \mathrm{c}:$ red square. The values were normalized regarding to the reference molecule for each experiments

The remarkable chemical and photophysical properties of those coumarinyl PPGs open the way for future developments using two-photon uncaging in neuroscience, ${ }^{9}$ cellular and molecular biology. ${ }^{4}$ But it should also be extremely beneficial for diverse applications in material sciences. ${ }^{34}$

\section{ASSOCIATED CONTENT}

\section{Supporting Information}

The Supporting Information is available free of charge on the ACS Publications website.

Experimental details, synthetic procedures, spectroscopic characterization and physical data determination (PDF).

\section{AUTHOR INFORMATION}

\section{Corresponding Author}

* E-mail: bolze@unistra.fr

* E-mail: gaelle.blond@unistra.fr

* E-mail: specht@unistra.fr

\section{Author Contributions}

The manuscript was written through contributions of all authors. / All authors have given approval to the final version of the manuscript. / \$These authors contributed equally.

\section{ACKNOWLEDGMENT}

The authors thank Estefania OLIVA for the LC-MS experiments. This work was supported by the Université de Strasbourg (IdEx Grant to A.S.), the CNRS, the French Infrastructure for Integrated 
Structural Biology (FRISBI) ANR-10-INSB-05, Instruct-ERIC, and by Grants from the Agence Nationale de la Recherche (Contract No. ANR-13-JSJV-0009-01 and ANR-18-CE09-0016-01 to A.S.).

\section{REFERENCES}

(1) Abou Nakad, E.; Chaud, J.; Morville, C.; Bolze, F.; Specht, A., Monitoring of uncaging processes by designing photolytical reactions. Photochemical \& Photobiological Sciences 2020, 19 (9), 1122-1133.

(2) Weinstain, R.; Slanina, T.; Kand, D.; Klán, P., Visible-to-NIRLight Activated Release: From Small Molecules to Nanomaterials. Chemical Reviews 2020, 120 (24), 13135-13272.

(3) Ankenbruck, N.; Courtney, T.; Naro, Y.; Deiters, A., Optochemical Control of Biological Processes in Cells and Animals. Angewandte Chemie International Edition, 2018, 57 (11), 2768-2798.

(4) Lin, Y.; Mazo, M. M.; Skaalure, S. C.; Thomas, M. R.; Schultz, S. R.; Stevens, M. M., Activatable cell-biomaterial interfacing with photo-caged peptides. Chemical Science 2019, 10 (4), 1158-1167.

(5) Shigeri, Y.; Tatsu, Y.; Yumoto, N., Synthesis and application of caged peptides and proteins. Pharmacology \& Therapeutics 2001, 91 (2), 85-92.

(6) Courtney, T.; Deiters, A., Recent advances in the optical control of protein function through genetic code expansion. Current Opinion in Chemical Biology 2018, 46, 99-107.

(7) Gautier, A.; Gauron, C.; Volovitch, M.; Bensimon, D.; Jullien, L.; Vriz, S., How to control proteins with light in living systems. Nature Chemical Biology 2014, 10 (7), 533-41.

(8) Ruble, B. K.; Yeldell, S. B.; Dmochowski, I. J., Caged oligonucleotides for studying biological systems. Journal of Inorganic Biochemistry 2015, 150, 182-188.

(9) Paoletti, P.; Ellis-Davies, G. C. R.; Mourot, A., Optical control of neuronal ion channels and receptors. Nature Reviews Neuroscience 2019, 20 (9), 514-532.

(10) Höglinger, D.; Nadler, A.; Schultz, C., Caged lipids as tools for investigating cellular signaling. Biochimica et Biophysica Acta (BBA) - Molecular and Cell Biology of Lipids 2014, 1841 (8), 1085-1096.

(11) W. Brown, W.; Deiters, A., Light-activation of Cre recombinase in zebrafish embryos through genetic code expansion. Methods in Enzymology, ed. A. Deiters, Academic Press, 2019, 624, 265-281.

(12) Goegan, B.; Terzi, F.; Bolze, F.; Cambridge, S.; Specht, A., Synthesis and Characterization of Photoactivatable Doxycycline Analogues Bearing Two-Photon-Sensitive Photoremovable Groups Suitable for Light-Induced Gene Expression. ChemBioChem, 2018, 19 (12), 1341-1348.

(13) Klausen, M.; Blanchard-Desce, M., Two-photon uncaging of bioactive compounds: Starter guide to an efficient IR light switch. Journal of Photochemistry and Photobiology C: Photochemistry Reviews 2021, 48, 100423.

(14) Ellis-Davies, G. C. R., Useful Caged Compounds for Cell Physiology. Accounts of Chemical Research 2020, 53 (8), 1593-1604.

(15) Klausen, M.; Dubois, V.; Verlhac, J.-B.; Blanchard-Desce, M., Tandem Systems for Two-Photon Uncaging of Bioactive Molecules. ChemPlusChem 2019, 84 (6), 589-598.

(16) Abe, M.; Chitose, Y.; Jakkampudi, S.; Thuy, P. T. T.; Lin, Q.; Van, B. T.; Yamada, A.; Oyama, R.; Sasaki, M.; Katan, C., Design and Synthesis of Two-Photon Responsive Chromophores for Near-Infrared Light-Induced Uncaging Reactions. Synthesis 2017, 49 (15), 33373346.

(17) Piant, S.; Bolze, F.; Specht, A., Two-photon uncaging, from neuroscience to materials. Opt. Mater. Express 2016, 6 (5), 1679-1691.

(18) Furuta, T.; Wang, S. S.-H.; Dantzker, J. L.; Dore, T. M.; Bybee, W. J.; Callaway, E. M.; Denk, W.; Tsien, R. Y., Brominated 7-hydroxycoumarin-4-ylmethyls: Photolabile protecting groups with biologically useful cross-sections for two photon photolysis. Proceedings of the National Academy of Sciences 1999, 96 (4), 1193-1200.

(19) Denk, W., Two-photon scanning photochemical microscopy: mapping ligand-gated ion channel distributions. Proceedings of the National Academy of Sciences 1994, 91 (14), 6629-6633.

(20) Weissleder, R., A clearer vision for in vivo imaging. Nature Biotechnology 2001, 19 (4), 316-317.

(21) Gug, S.; Bolze, F.; Specht, A.; Bourgogne, C.; Goeldner, M.; Nicoud, J.-F., Molecular Engineering of Photoremovable Protecting Groups for Two-Photon Uncaging. Angewandte Chemie International Edition 2008, 47 (49), 9525-9529.

(22) He, G. S.; Tan, L.-S.; Zheng, Q.; Prasad, P. N., Multiphoton Absorbing Materials: Molecular Designs, Characterizations, and Applications. Chemical Reviews 2008, 108 (4), 1245-1330.

(23) Klausen, M.; Dubois, V.; Clermont, G.; Tonnelé, C.; Castet, F.; Blanchard-Desce, M., Dual-wavelength efficient two-photon photorelease of glycine by $\pi$-extended dipolar coumarins. Chemical Science 2019, 10 (15), 4209-4219.

(24) Bojtár, M.; Kormos, A.; Kis-Petik, K.; Kellermayer, M.; Kele, P., Green-Light Activatable, Water-Soluble Red-Shifted Coumarin Photocages. Organic Letters 2019, 21 (23), 9410-9414.

(25) Lin, Q.; Yang, L.; Wang, Z.; Hua, Y.; Zhang, D.; Bao, B.; Bao, C.; Gong, X.; Zhu, L., Coumarin Photocaging Groups Modified with an Electron-Rich Styryl Moiety at the 3-Position: Long-Wavelength Excitation, Rapid Photolysis, and Photobleaching. Angewandte Chemie International Edition 2018, 57 (14), 3722-3726.

(26) Chitose, Y.; Abe, M.; Furukawa, K.; Lin, J.-Y.; Lin, T.-C.; Katan, C., Design and Synthesis of a Caged Carboxylic Acid with a Donor $-\pi-$ Donor Coumarin Structure: One-photon and Two-photon Uncaging Reactions Using Visible and Near-Infrared Lights. Organic Letters 2017, 19 (10), 2622-2625.

(27) Richers, M. T.; Amatrudo, J. M.; Olson, J. P.; Ellis-Davies, G. C. R., Cloaked Caged Compounds: Chemical Probes for Two-Photon Optoneurobiology. Angew Chem Int Ed Engl 2017, 56 (1), 193-197.

(28) Morville, C.; Chaud, J.; Bolze, F.; Specht, A., Photolytical reactions for light induced biological effectors release: on the road to the phototherapeutic window. Journal of Inclusion Phenomena and Macrocyclic Chemistry 2021 in press, https://doi.org/10.1007/s10847-02101071-9.

(29) Blouin, S.; Blond, G.; Donnard, M.; Gulea, M.; Suffert, J., Cyclocarbopalladation as a Key Step in Cascade Reactions: Recent Developments. Synthesis 2017, 49 (08), 1767-1784.

(30) Düfert, A.; Werz, D. B., Carbopalladation Cascades Using Carbon-Carbon Triple Bonds: Recent Advances to Access Complex Scaffolds. Chemistry - A European Journal 2016, 22 (47), 16718-16732.

(31) de Meijere, A.; Schelper, M.; Knoke, M.; Yucel, B.; Sünnemann, H. W.; Scheurich, R. P.; Arve, L., Palladium-catalyzed crosscoupling reactions and electrocyclizations-efficient combinations for new cascade reactions. Journal of Organometallic Chemistry 2003, 687 (2), 249-255.

(32) Seyfried, P.; Eiden, L.; Grebenovsky, N.; Mayer, G.; Heckel, A., Photo-Tethers for the (Multi-)Cyclic, Conformational Caging of Long Oligonucleotides. Angewandte Chemie International Edition 2017, 56 (1), 359-363.

(33) Eckardt, T.; Hagen, V.; Schade, B.; Schmidt, R.; Schweitzer, C.; Bendig, J., Deactivation Behavior and Excited-State Properties of (Coumarin-4-yl)methyl Derivatives. 2. Photocleavage of Selected (Coumarin-4-yl)methyl-Caged Adenosine Cyclic 3',5'-Monophosphates with Fluorescence Enhancement. The Journal of Organic Chemistry 2002, 67 (3), 703-710.

(34) Zheng, Y.; Farrukh, A.; Del Campo, A., Optoregulated Biointerfaces to Trigger Cellular Responses. Langmuir : the ACS journal of surfaces and colloids 2018, 34 (48), 14459-14471. 